\title{
Correction: The role of IL-17A in axial spondyloarthritis and psoriatic arthritis: recent advances and controversies. A meta- analysis and functional study
}

McGonagle DG, McInnes IB, Kirkham BW, et al. The role of IL-17A in axial spondyloarthritis and psoriatic arthritis: recent advances and controversies. A meta-analysis and functional study. Ann of Rheum Dis 2019;78:1167-78. doi: 10.1136/annrheumdis-2019-215356.

Figure 4 is amended to reflect the lack of definitive, controlled clinical evidence of prevention of structural progression by secukinumab in axial spondyloarthritis.

\begin{tabular}{|c|c|c|}
\hline & Secukinumab ${ }^{12-16,20,21,188,232-2255}$ & |xekizumab ${ }^{17-19,169,236,237}$ \\
\hline Approved indications & Psoriasis, PsA, AS & Psoriasis, PsA \\
\hline MoA & Fully-human anti-IL-17A antibody & Humanised anti-IL-17A antibody \\
\hline \multicolumn{3}{|l|}{ PsA } \\
\hline Peripheral arthritis & - & - \\
\hline Enthesitis & - & - \\
\hline Dactylitis & - & - \\
\hline Skin & - & ○ \\
\hline Nail & ? & ○ \\
\hline Axial disease & P & 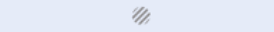 \\
\hline Structural progression & - & - \\
\hline \multicolumn{3}{|l|}{ AS } \\
\hline Signs and symptoms & - & ○ \\
\hline Disease activity & - & - \\
\hline Function & - & - \\
\hline Structural progression & ○ & O \\
\hline Non-radiographic axial SpA & O & O \\
\hline Psoriasis & - & ○ \\
\hline Crohn's disease & - & 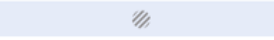 \\
\hline Uveitis $^{n}$ & $\Rightarrow$ & $\dddot{1}$ \\
\hline
\end{tabular}

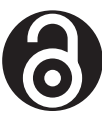

\section{OPEN ACCESS}

Open access This is an open access article distributed in accordance with the Creative Commons Attribution Non Commercial (CC BY-NC 4.0) license, which permits others to distribute, remix, adapt, build upon this work noncommercially, and license their derivative works on different terms, provided the original work is properly cited, appropriate credit is given, any changes made indicated, and the use is non-commercial. See: http://creativecommons.org/licenses/by-nc/ 4.0\%.

(C) Author(s) (or their employer(s)) 2020. Re-use permitted under CC BY-NC. No commercial re-use. See rights and permissions. Published by BMJ.

Ann Rheum Dis 2020;79. doi:10.1136/annrheumdis-2019-215356corr1

Check for updates 